\title{
Stratigraphy, tephrochronology, and structural setting of Miocene sedimentary rocks in the Cobble Cuesta area, west- central Nevada
}

By John H. Stewart, Andrei Sarna-Wojcicki, and Charles E. Meyer, and Elmira Wan

U.S. Geological Survey, 345 Middlefield Road, Menlo Park, California, 94025

Open File Report 99-352

1999

This report is preliminary and has not been reviewed for conformity with U.S. Geological

Survey editorial standards or with the North American Stratigraphic Code. Any use of trade, product or firm names is for descriptive purposes only and does not imply endorsement by the U.S. Government.

U.S. DEPARTMENT OF INTERIOR

U.S. GEOLOGICAL SURVEY 


\section{CONTENTS}

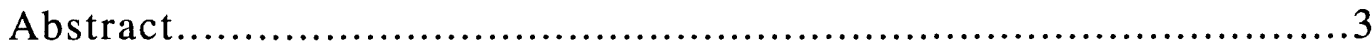

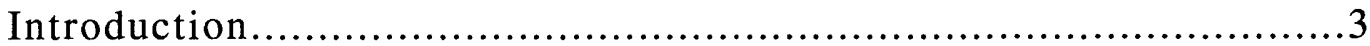

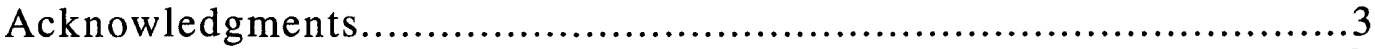

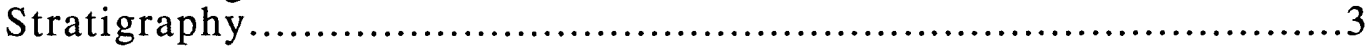

Map unit Ts........................................................

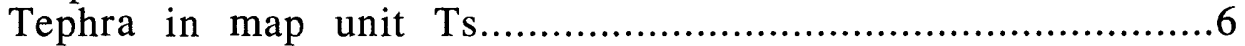

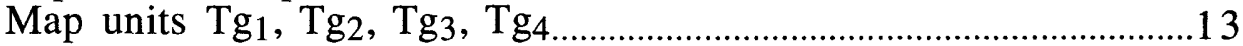

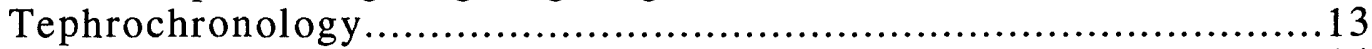

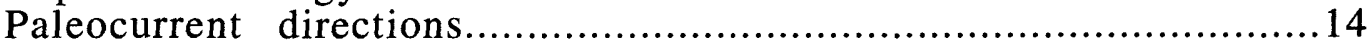

Environments of deposition...................................................14

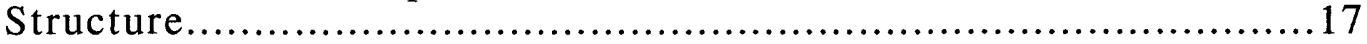

Paleogeography and structural setting............................................17

References cited

\section{FIGURES}

1. Index map showing location of Cobble Cuesta area, west-central Nevada...............4

2. Index map of Gabbs Valley area showing location of major known or inferred basin-and-range faults.

3. Geologic map of Cobble Cuesta area ..........................................(in pocket)

4. Stratigraphic diagram of Miocene strata in Cobble Cuesta area..............................7

5. Stratigraphic column showing relative position of tephra samples.......................11

6. Rose diagram showing summary of all paleocurrent measurements in Cobble

Cuesta area. Total number of readings (N) is 251 . Measurements consist of dip direction of individual cross-strata, trends of trough sets of cross-strata and of channels, and of the dip direction of individual disk- or blade-shaped clasts. The dip direction of imbricated clasts, which are inclined upcurrent, are rotated 180 degrees so that the information is consistent with the downcurrent direction of cross-strata, troughs, and channels. Measurements corrected for structural dip....

7. Rose diagrams showing paleocurrent information at localities in Cobble

Cuesta area. Symbols: x-strata, paleocurrent data from cross-strata or trend of trough sets of cross-strata; imb, paleocurrent data from imbrication; ch, paleocurrent data from channels trends; $N$, number of readings at locality. See caption of figure 4 for additional information on character of data.

8. Interpretive diagram showing development of Gabbs Valley basin. Hachured

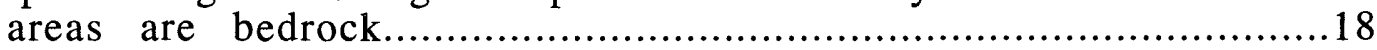

\section{TABLES}

1. Chemical composition of volcanic glass shards in tephra layers in Cobble Cuesta area Major element chemistry of tephra in Cobble Cuesta area..........................8

2. Summary of correlation and age of tephra in Cobble Cuesta area, based on major element analysis............................................................. 


\section{Abstract}

About $850 \mathrm{~m}$ of Miocene strata are exposed in the Cobble Cuesta area of the Gabbs Valley basin, Nye County, Nevada. Gravity studies suggest that as much as $4,000 \mathrm{~m}$ of late Cenozoic sedimentary rock may underlie Gabbs Valley. Based on tephrochronological studies the strata range in age from 12.96 to $<9.24 \mathrm{Ma}$. The strata consist of lacustrine siltstone and sandstone, fluvial and deltaic sandstone and conglomerate, and, in the upper part, of alluvial-fan conglomerate. Paleocurrent studies indicate transport directions to the south. Apparent unconformities in the Miocene strata suggest that structural movement, presumably normal fault displacements, started about $11 \mathrm{Ma}$, along the west side of the Gabbs Valley basin, but the general fine-textured character of the sedimentary rocks of this age indicate that the depositional basin was larger than the present-day size of Gabbs Valley. A major unconformity $(<9.24 \mathrm{Ma})$ in the section marks a distinct lithologic change to coarse alluvial-fan conglomerate and to a topography similar to that of the present-day. A major anticline, the Cobble Cuesta anticline, is centered on Cobble Cuesta. This anticline is defined by Miocene strata as young as, and younger than, $9.24 \mathrm{Ma}$, and is interpreted to be an anticlinal accommodation zone produced by backward rotation (reverse drag producing west-dipping strata) along east-dipping normal faults on the west side of Gabbs Valley and the opposite direction of rotation and tilt on west-dipping faults on the east side of Gabbs Valley. In this situation, an extensional anticline is produced in the central part of Gabbs Valley.

\section{Introduction}

The Cobble Cuesta area is in Gabbs Valley, Nye and Mineral Counties, Nevada, about $165 \mathrm{~km}$ east southeast of Reno, Nevada (Fig. 1,2). The area contains a remarkable unfaulted 850-m-thick succession of Miocene fluvial, deltaic, and lacustrine sedimentary strata. These strata were mapped at a 1:250,000 scale by Kleinhampl and Ziony (1985) and at a 1:48,000 scale by Ekren and Byers (1986). The present field study was done in 1990,1992 , and 1993, and consisted of field mapping, measurement of stratigraphic sections, studies of paleocurrent directions, and collection of samples for tephrochronologic studies. Some preliminary results of this study were published by Stewart (1992). Tephrochronological studies and preparation of this report was done in 1994-1998. In addition to the Miocene sedimentary rocks, the map area includes outcrops of Permian or Triassic sedimentary, igneous, and volcanic sedimentary rocks; Jurassic or Cretaceous and granitic rocks; and Oligocene and Miocene volcanic rocks. Descriptions of these older rocks are given by Ekren and Byers $(1976 ; 1986)$ and Ekren and others (1980). Companion studies have been made of Miocene strata in the Middlegate area (Stewart and others, 1999) and the Trinity Range-Hot Springs Mountains area (Stewart and Perkins, 1999)

\section{Acknowledgments}

We wish to thank Andrew Brownstone and Drew Eriksson for their help in processing the tephrochronolgy samples.

\section{Stratigraphy}

Map unit Ts: Miocene (13- to $<9.8 \mathrm{Ma}$ ) clastic sedimentary strata exposed in the Cobble Cuesta area (Fig. 1,2) about $850 \mathrm{~m}$ thick and consist of a lower unit of tuffaceous sandstone and granule to pebble conglomerate (map unit Ts) and an overlying sequence of conglomerate or gravel (map units $\mathrm{Tg}_{1}, \mathrm{Tg}_{2}, \mathrm{Tg}_{3}$, and $\mathrm{Tg}_{4}$ ). The tuffaceous sandstone and sandstone in map unit Ts is yellow gray to very light gray, fine to very coarse grained, and poorly sorted. It is composed of subangular to subrounded quartz, feldspar, pumaceous material, volcanic lithic grains, and minor amounts of biotite and other mafic minerals. The 


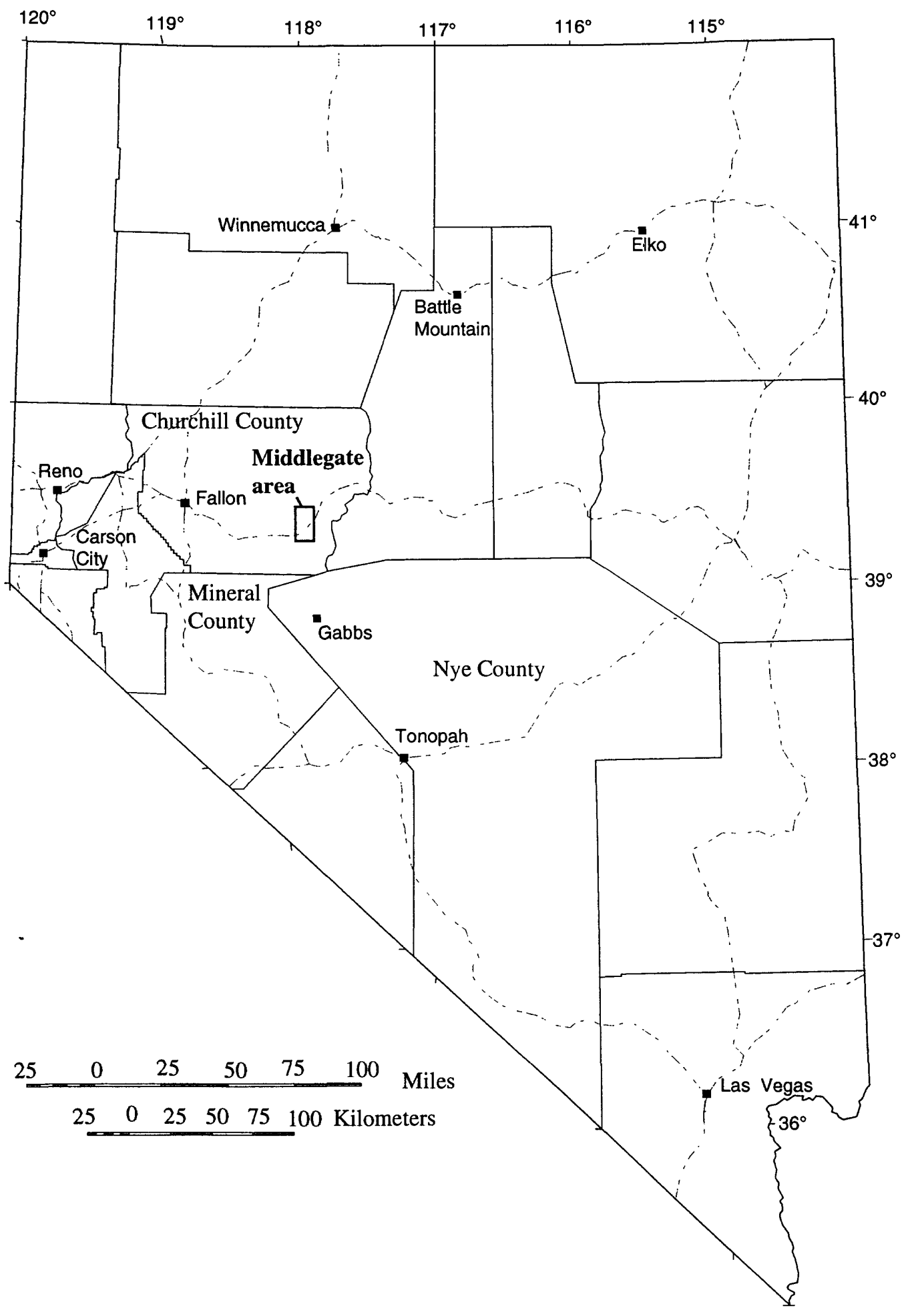

Figure 1. Index map showing location of Cobble Cuesta, west-central Nevada 


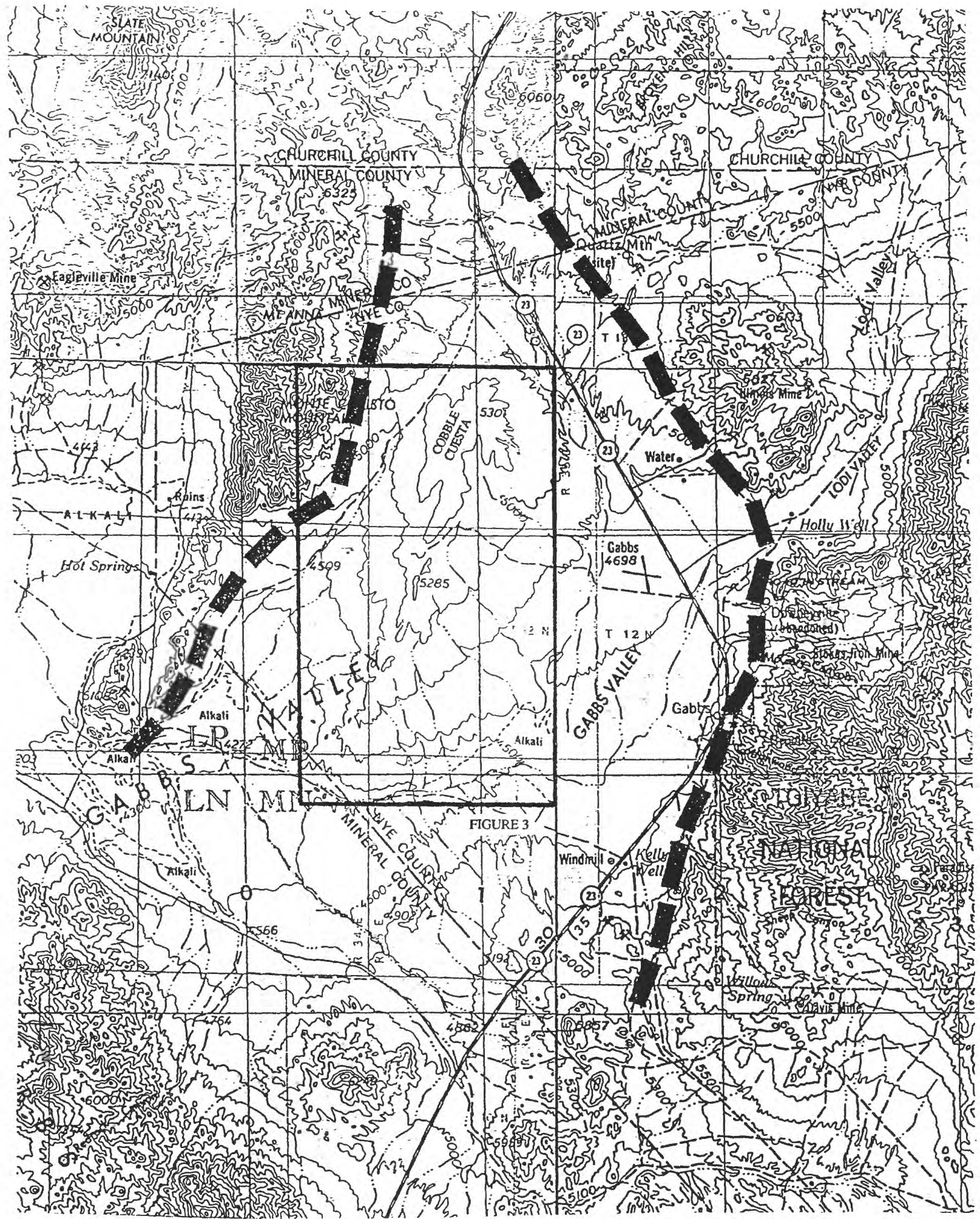

\section{EXPLANATION}

Known or inferred major basin-and-range fault or fault zone-Gabbs Valley on the downthrown side

Figure 2. Index map of Gabbs Valley area showing location of major known or inferred basin- and-range faults 
stratification is generally difficult to see, but where visible is laminated to thin bedded or cross-stratified. The cross-strata are mostly in small-scale trough sets. The tuffaceous sandstone and sandstone are in most places only slightly indurated and are poorly exposed in areas of low relief. Locally, the tuffaceous sandstone and sandstone are indurated by a calcareous or siliceous cement, and in these places form resistant ledges that stand out within areas of low relief. In an area centered near Long. $118^{\circ} 51^{\prime} \mathrm{W}$, Lat. $38^{\circ} 57^{\prime \prime} \mathrm{N}$, the tuffaceous sandstone and sandstone are fairly well indurated, is cross-stratified, and contain silicified tree logs. In this area, small-scale trough cross strata predominate, but large-scale cross-stratified sets, considered to be delta foreset deposits, are also present.

The granule to pebble conglomerate is interlayered with the tuffaceous sandstone and sandstone. The conglomerate is yellow gray to moderate yellow brown and consists of subangular to subrounded granules to pebbles of flow-banded rhyolite, glassy rhyolite, welded tuff, fine-grained andesite, coarse-grained hornblende andesite, and lesser amounts of more mafic fine-grained volcanic rocks, chalcedony, jasper, feldspar, aplite, and apache tears (rounded black obsidian fragments that are the unaltered internal remnants of a hydrated glass). The clast mostly range in size from 1 to $4 \mathrm{~cm}$, but some clasts are as large as about $20 \mathrm{~cm}$. The aplite and feldspar clasts were noted in stratigraphic section 4 between tephra layers $\mathrm{A}$ and $\mathrm{C}$. The feldspar clasts are locally as large as $2 \mathrm{~cm}$, suggesting a granitic source terrain. The granule and pebble conglomerate is generally poorly indurated, nonresistant and its internal stratification difficult to see. It is present in approximately 1- to 20-m-thick layers interstratified with the tuffaceous sandstone and sandstone.

Conglomerate is conspicuously more abundant in the northern part of the map area in and near stratigraphic section 4 (Fig. 4)

In addition to tuffaceous sandstone, sandstone, and conglomerate, map unit Ts locally contains claystone, silty claystone, and clayey siltstone. These clay-rich strata are yellow gray to light olive gray and generally contain clays that swell on contact with water. Stratification is generally not evident.

The lower half or two-thirds of map unit Ts shows a change from stratigraphic section 4 (Fig.4) where it contains abundant conglomerate (stratigraphic section 4, Fig. 4) to stratigraphic section 1 (Fig. 4) where it consists dominantly of sandstone and, in the lower part, of claystone, silty claystone, and clayey siltstone.

Tephra in map unit Ts. Map unit Ts is characterized by tephra layers that form conspicuous white to yellow-gray bands along the outcrop within an otherwise homogeneous section. The tephra layers or subunits range from individual airfall tuff only a few centimeters thick to subunits as thick as about $20 \mathrm{~m}$ that contain several airfall tuffs, or airfall tuffs in association with water-reworked tuffs.

On the map, nine major tephra layers, or subunits, are mapped and designated by a letter symbol, or a letter symbol and a number. These consist, from bottom to top, of tephra A, C-3, B, C-2, C, D, EL, EU, and E+1. In addition to these lettered tephra layers, other less extensive layers are shown on the map. Finally, other tephra layers are locally present in the map area but are too restricted in distribution to be shown. Samples for chemical analysis were taken from the lettered tephra as well as other mapped, or unmapped, tephra layers in the map area (Table 1,2; Fig. 5)).

Tephra layer A (tephra sample 13384-7J) crops out in the northern two-thirds of the map. At stratigraphic section 4 it is $4.8 \mathrm{~m}$ thick and consists of very-light- to mediumlight-gray vitric-ash tuff with 1 to $2 \mathrm{~mm}$ shards. It is indistinctly laminated to thinly bedded. About $1.5 \mathrm{~km}$ west of stratigraphic section 3, it consists of a meter-thick layer of vitric-ash. Here it is overlain by $5 \mathrm{~m}$ of tuffaceous siltstone that appears to be in part waterreworked ash.

Tephra layer C-3 (tephra sample 2379-17JB) crops out only in one area in the southernmost part of the Mount Annie NE quadrangle near stratigraphic section 1. At stratigraphic section 1 , it is a 1-m-thick layer of very-light-gray vitric ash tuff that has indistinct laminae to thin beds and minor, small soft-sediment folds. 

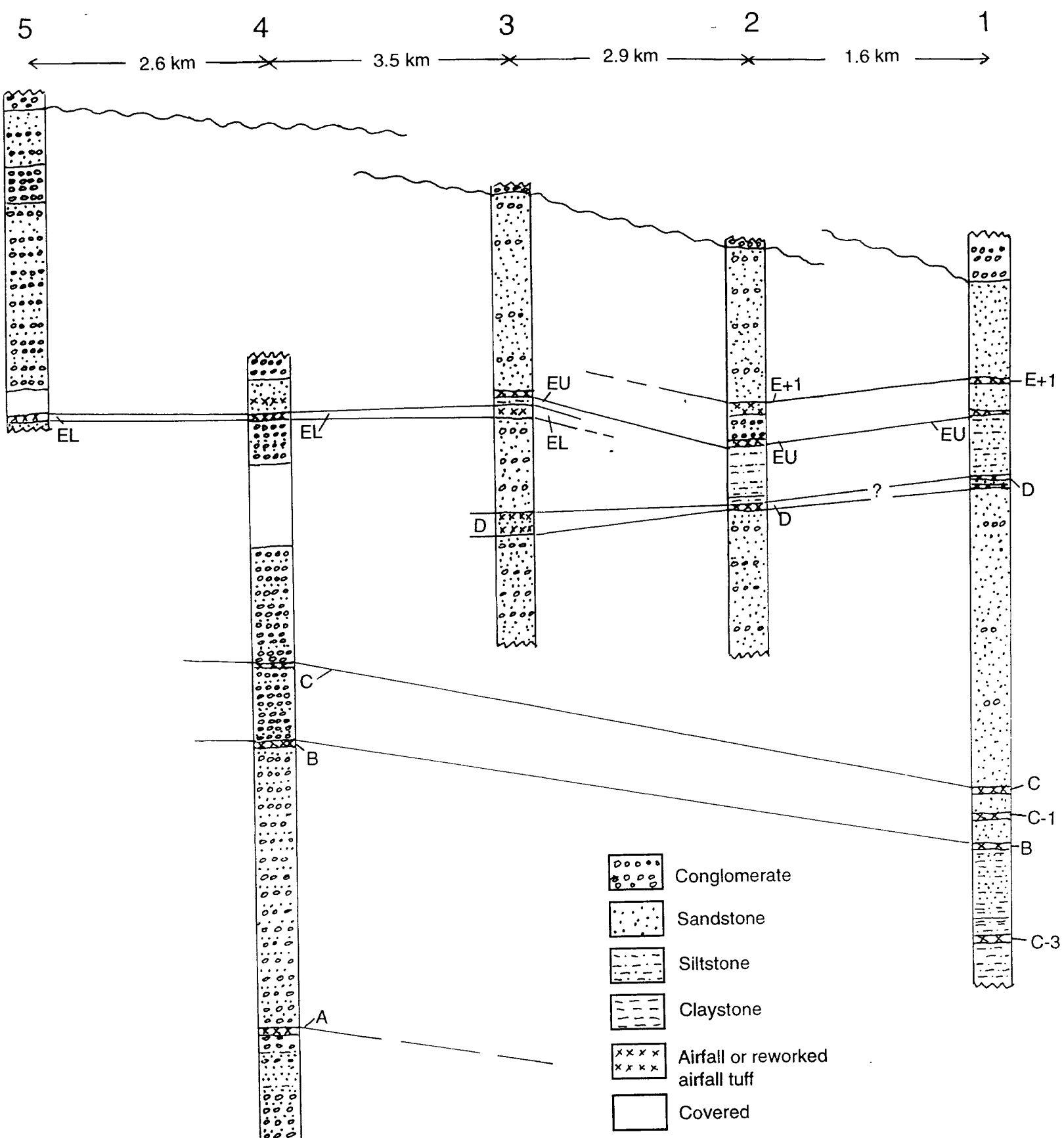

Figure 4. Stratigraphic diagram of Miocene strata in Cobble Cuesta area 
Table 1. Chemical composition of volcanic glass shards in tephra layers of the Cobble Cuest area, Nevada, as determined by electron-microprobe analysis. Samples listed in stratigraphic order from youngest to oldest. See figure 5 for relative positions of samples. Values shown below represent the average of between about 15 and 20 analyzed shards for each sample. Some samples have more than one compositional mode. The modes are: ma -major mode; mi - minor mode; hi Ca - high $\mathrm{CaO}$; lo $\mathrm{Ca}$ - low $\mathrm{CaO} ; 1$ sh, one shard analyzed. Results of replicate analysis of a homogenous internal glass standard, RLS132, are given below to provide an approximation of analytical precision. Analyses by Charles E. Meyer, U.S. Geological Survey, Menlo Park, Calif., using the JEOL 8900 instrument.

\begin{tabular}{|c|c|c|c|c|c|c|c|c|c|c|}
\hline Sample No. & $\mathrm{SiO} 2$ & Al2O3 & $\mathrm{Fe} 2 \mathrm{O} 3$ & $\mathrm{MgO}$ & $\mathrm{MnO}$ & $\mathrm{CaO}$ & TiO2 & $\mathrm{Na} 2 \mathrm{O}$ & $\mathrm{K} 2 \mathrm{O}$ & Total, R \\
\hline JS-92-67 & 70.63 & 15.91 & 1.60 & 0.25 & 0.11 & 0.89 & 0.29 & 5.13 & 5.18 & 99.99 \\
\hline $2-96-47 \mathrm{~J}$ & 69.80 & 16.09 & 1.83 & 0.38 & 0.09 & 1.15 & 0.36 & 4.75 & 5.55 & 100.00 \\
\hline $2-94-16 \mathrm{~J}$ & 75.20 & 12.57 & 2.15 & 0.15 & 0.04 & 0.81 & 0.38 & 2.87 & 5.84 & 100.00 \\
\hline JS-92-66 (ma) & 75.89 & 11.54 & 2.35 & 0.05 & 0.14 & 0.10 & 0.20 & 5.24 & 4.49 & 100.00 \\
\hline JS-92-66 (mi) & 74.30 & 12.78 & 2.60 & 0.12 & 0.07 & 0.90 & 0.32 & 3.21 & 5.70 & 100.00 \\
\hline $2379-12 \mathrm{~J}$ & 74.54 & 12.68 & 2.51 & 0.15 & 0.03 & 0.95 & 0.38 & 3.17 & 5.59 & 100.00 \\
\hline $2-96-46 \mathrm{~J}$ & 75.20 & 12.56 & 2.55 & 0.13 & 0.04 & 0.90 & 0.33 & 3.20 & 5.34 & 100.25 \\
\hline JS-92-65 & 75.84 & 13.85 & 0.97 & 0.17 & 0.10 & 0.84 & 0.11 & 3.90 & 4.22 & 100.00 \\
\hline $2-96-38 \mathrm{~J}$ & 75.76 & 11.96 & 2.60 & 0.08 & 0.04 & 0.78 & 0.29 & 2.76 & 5.92 & 100.19 \\
\hline JS-92-64 & 76.08 & 12.24 & 2.15 & 0.04 & 0.02 & 0.69 & 0.23 & 2.38 & 6.17 & 100.00 \\
\hline JS-92-64 & 75.30 & 12.44 & 2.36 & 0.03 & 0.04 & 0.64 & 0.23 & 2.53 & 6.41 & 99.98 \\
\hline JS-92-63 (hi Ca) & 76.95 & 12.89 & 0.75 & 0.10 & 0.06 & 0.66 & 0.09 & 3.19 & 5.31 & 100.00 \\
\hline JS-92-63 (1o Ca) & 76.75 & 12.73 & 0.73 & 0.05 & 0.06 & 0.39 & 0.10 & 2.89 & 6.31 & 100.01 \\
\hline JS-92-63 (Ma) & 76.90 & 12.84 & 0.75 & 0.08 & 0.06 & 0.59 & 0.09 & 3.11 & 5.58 & 100.00 \\
\hline JS-92-62 & 75.95 & 13.88 & 1.01 & 0.27 & 0.12 & 1.12 & 0.10 & 3.29 & 4.26 & 100.00 \\
\hline $2-57-22 \pi B(1 \mathrm{sh})$ & 74.07 & 14.84 & 1.27 & 0.27 & 0.05 & 1.96 & 0.12 & 3.20 & 4.21 & 99.99 \\
\hline $13384-9 \mathrm{~J}$ & 78.12 & 12.27 & 0.51 & 0.08 & 0.07 & 0.50 & 0.08 & 2.39 & 5.98 & 100.00 \\
\hline $2379-19 \mathrm{~J}$ & 78.09 & 12.27 & 0.51 & 0.07 & 0.07 & 0.52 & 0.08 & 2.71 & 5.68 & 100.00 \\
\hline $2379-5 J B$ & 76.96 & 12.98 & 0.62 & 0.08 & 0.07 & 0.54 & 0.10 & 2.68 & 5.98 & 100.01 \\
\hline 2379-1JA & 76.99 & 13.12 & 0.54 & 0.07 & 0.06 & 0.55 & 0.09 & 3.39 & 5.20 & 100.01 \\
\hline $2-94-3 J$ & 76.85 & 12.83 & 0.49 & 0.05 & 0.07 & 0.42 & 0.08 & 2.84 & 6.36 & 99.99 \\
\hline $2379-15 \mathrm{~J}$ & 76.23 & 12.12 & 1.84 & 0.08 & 0.02 & 0.58 & 0.24 & 2.76 & 6.13 & 100.00 \\
\hline $2-94-4 \mathrm{~J}$ & 77.25 & 12.78 & 0.49 & 0.05 & 0.07 & 0.40 & 0.08 & 2.55 & 6.47 & 100.14 \\
\hline $2-96-31 \mathrm{~J}$ & 76.63 & 11.99 & 1.85 & 0.07 & 0.02 & 0.58 & 0.25 & 2.33 & 6.52 & 100.24 \\
\hline $2-96-43 J$ & 77.11 & 12.45 & 0.89 & 0.13 & 0.05 & 0.57 & 0.16 & 2.95 & 5.74 & 100.05 \\
\hline $2379-14 \mathrm{~J}$ & 77.21 & 12.60 & 0.53 & 0.06 & 0.06 & 0.36 & 0.09 & 3.33 & 5.77 & 100.01 \\
\hline $13384-8 \mathrm{~J}$ & 78.05 & 12.16 & 0.52 & 0.04 & 0.06 & 0.37 & 0.08 & 2.42 & 6.30 & 100.00 \\
\hline $2-57-16 \mathrm{~J}$ & 75.97 & 12.37 & 2.19 & 0.07 & 0.03 & 0.69 & 0.25 & 2.08 & 6.35 & 100.00 \\
\hline 2379-17JB & 76.74 & 12.25 & 2.12 & 0.07 & 0.04 & 0.67 & 0.25 & 3.61 & 4.25 & 100.00 \\
\hline 13384-7J & 77.39 & 11.75 & 1.73 & 0.05 & 0.03 & 0.58 & 0.18 & 2.26 & 6.01 & 99.98 \\
\hline
\end{tabular}

Homogenous glass standard, analyzed by the SEMQ (S) and JEOL (J) electron-microprobes

$\begin{array}{lcccccccccr}\mathrm{RLS132}(\mathrm{S}) & 75.37 & 11.26 & 2.12 & 0.06 & 0.16 & 0.11 & 0.19 & 4.88 & 4.42 & 100.00 \\ \pm 1 \sigma(\mathrm{n}=18) & 0.57 & 0.16 & 0.04 & 0.01 & 0.01 & 0.01 & 0.01 & 0.13 & 0.06 & 0.78 \\ & & & & & & & & & & \\ \mathrm{RLS132}(\mathrm{J}) & 74.40 & 11.51 & 2.13 & 0.05 & 0.16 & 0.10 & 0.19 & 5.23 & 4.41 & 100.00 \\ \pm 1 \sigma(\mathrm{n}=28) & 0.34 & 0.10 & 0.06 & 0.004 & 0.01 & 0.01 & 0.01 & 0.13 & 0.04 & 0.48\end{array}$


Table 2. Summary of correlation and age of tephra in Cobble Cuesta area based on major element analysis (Table 1). Sample numbers in bold type are from this report. Unless otherwise indicated, the tephra are from eruptions in the Snake River Plain

JS-92-67, local tuff, correlative with rocks in the Aldrich Station area in western Nevada (BE-103, BE-54, Eastwood, 1969) that are probably younger than $9.8 \mathrm{Ma}$. Very much like ash flows just east of Sonora, California. Probable source in Little Walker River Caldera.

2-96-47J, local tuff (probably lower than JS-92-67, but not certain). Possible source in Little Walker River Caldera, California

2-94-16J (tephra layer E+1) Correlated with tuff of Mink Creek in Rush Valley, Utah, that has an interpolated age of 9.24 Ma (Perkins and others, 1998).

JS-92-66, 2379-12J, and 2-96-46J (tephra layer EU): JS-92-66, two modes, both probably from southern Nevada source, no good chemical correlation to other tephra. 2379-12J, probably southern Nevada source, correlates with QD3-41 and QC-40 at Hazen, Nevada, which lie close to tephra dated as $9.79 \mathrm{Ma}$ by F.H. Brown (Perkins and others, 1998). 2-96-46J, chemically similar to QA-9 (DK) at Hazen, Nevada, considered to be $12 \mathrm{~m}$ below layer dated by K-Ar methods as 9.79 Ma by F.H. Brown (Perkins and others, 1998).

JS-92-65 (tephra layer EL), unusual chemistry, possibly southern Nevada source; no good chemical correlation to other tephra.

2-96-38J, local tephra layer, about halfway between tephra layer D and E. Matches: 1) BE-220 and BE-253 in the upper part of the Coal Valley Formation, Aldrich Station, Nevada (Eastwood, 1969); 2) epb92-23 (tuff of Opal Canyon 2) in the El Paso basin, California, with an interpolated age of $10.54 \mathrm{Ma}$ (Perkins and others, 1998); 3) 1-36-23J in the Middlegate area (unit Tmmrb, Stewart and others, 1999); 4) 1-12-5J in the Middlegate area (unit Tmu, Stewart and others, 1999), 5) 1-12-9J in the Middlegate area (unit Tml, Stewart and others, 1999), and 5) 1-3535J in the Middlegate area (unit Tmmss, Stewart and others, 1999).

JS-92-64 (top tuff of tephra layer D), correlates with BE-268 at Aldrich Station, Nevada and probably with TC89-31a at Trapper Creek in south-central Idaho that has an interpolated age of $10.94 \mathrm{Ma}$ (Perkins and others, 1998).

JS-92-63 (middle tuff of tephra layer D), correlates 1) with BE-62 (Eastwood, 1969) at Aldrich Station, Nevada; 2) possibly with FL-KA-32, an 11.0 Ma rhyolite tuff in Fish Lake Valley, California and Nevada, 3) with MM-BH-1, a tephra layer dated as about $11.1 \mathrm{Ma}$ in tuffaceous Miocene sedimentary rocks south of Lake Tecopa, southeastern California (M. McMackin, personal commun., 1996).

JS-92-62 (lower tuff of tephra layer D), chemically distinct, possible unusual source (Cascade volcanic field?). Chemically very similar to reworked tuff in the Neroly Formation. The Neroly Formation consists of alluvium composed of basaltic and/or andesitic alluvium derived from the Sierra Nevada and transported to the central California Coast Ranges.

2-57- 22JB, local tuff, halfway between tephra layers $C$ and $D$, insufficent chemical data to characterize.

2-57-22JA, local tuff, halfway between tephra layers $C$ and D, sample totally altered. Not analyzed.

13384-9J and 2379-19J (tephra layer C), correlated with i88-54a in Ibapah badlands, Nevada, 11.51 Ma (Perkins and others, 1998) which is considered to have a southern Nevada source. Tephra layer $\mathrm{C}$ is a coarse ash to lapilli tuff that probably had as source near Cobble Cuesta. If so, the correlation of tephra layer $C$, which has a source near Cobble Cuesta, and the tuff in Ibapah badlands, which has a source in southern Nevada, is either wrong, or the tuff in the Ibapah badlands was derived from a source near Cobble Cuesta and the supposed southern Nevada source for is wrong. 
Table 2 continued

2379-5JB, Probably tephra layer C, southern Nevada source. No close chemical matches with other tephra.

2379-1JA, correlates with BE-25 (Eastwood, 1969) at Aldrich Station, Nevada, that is a short distance above tuff dated as 11.2 Ma. Southern Nevada source. Also similar to tuff in the Briones Formation, with underlies the Neroly Formation, in the central Coast Ranges of California.

2-94-3J, local tephra layer, $2.7 \mathrm{~m}$ above $2379-15 J$. Chemically similar to southern Nevada tephra. Similar to 2-94-4J. Correlation uncertain.

2379-15J (tephra layer C-1), correlate with TC89-25a at Trapper Creek, Idaho that has an interpolated age of 11.59 Ma. Similar to BE-23 (Eastwood, 1969) at Aldrich Station, Nevada, close to a layer dated as $11.2 \mathrm{Ma}$.

2-94-4J, local thin tephra directly below tephra layer C-1. See 2-94-3J above.

2-96-31J, local tephra layer between tephra layer B and C, could be near position of tephra layer $\mathrm{C}-1$, or same tuff as tephra layer $\mathrm{C}-1$, but position not known precisely. Chemically similar to 2379-15J. Correlates with matches TC89-25a at Trapper Creek, Idaho, that has an interpolated age of 11.59 Ma (Perkins and others, 1998).

2-96-43J, local tephra layer $22.3 \mathrm{~m}$ above tephra layer B. Correlated with tuff of Browns Hill 3 (i88-48) that has an interpolated age of $11.66 \mathrm{Ma}$ (Perkins and others, 1998). Questionably similar to southern or southeastern Nevada tephra.

2379-14J and 13384-8J, tephra layer B, correlates with wb93-320 (tuff of Overnight) that has an interpolated age of 11.78 (Perkins and others, 1998). Southern Nevada source.

2-57-16J, local tephra layer, $61.0 \mathrm{~m}$ below tephra layer B, could be close to position of tephra layer C-3. Chemically matches "Boswell tephra" which includes TC 89-21 A at Trapper Creek, Idaho, with an age of $11.93 \mathrm{Ma}$ (Perkins and others, 1998).

2379-17JB, tephra layer C-3, chemically matches 2-57-16J, and thus "Boswell tephra" dated as $11.93 \mathrm{Ma}$ (see 2-57-16J).

13384-7J, tephra layer A. Correlated with TC-89-20a at Trapper Creek, Idaho, that has an age of 12.96 (Perkins and others, 1998) 
AGE (Ma)

based

on tephro-

chronology
SAMPLES (listed in stratigraphic position based on field mapping. Vertical distances do not indicate stratigraphic thickness.

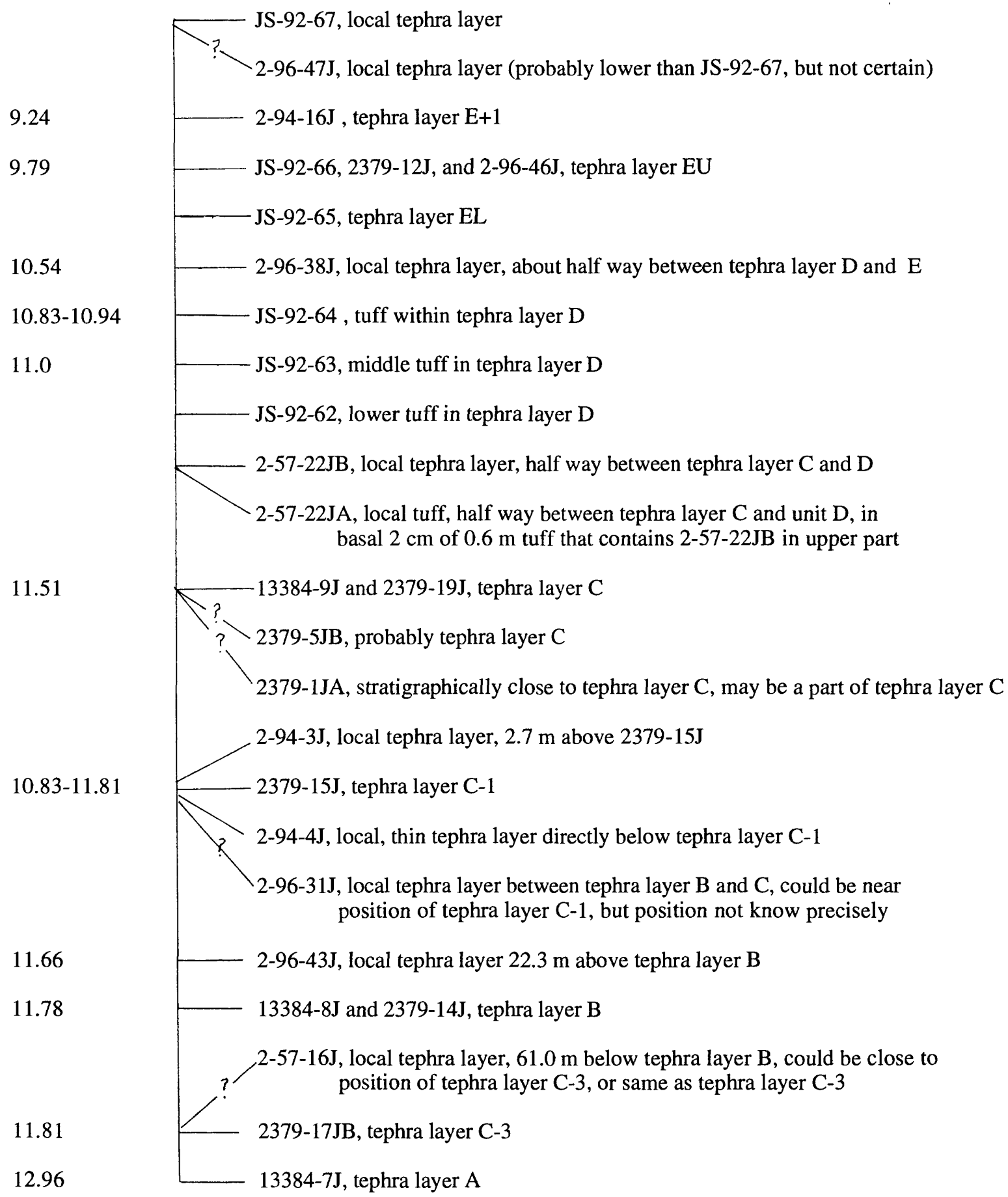

Figure 5. Stratigraphic column showing relative location of tephra samples 
Tephra layer B (tephra samples 13384-8J and 2379-14J) crops out along almost all of the outcrop area of map unit Ts in the Mount Annie NE quadrangle. At stratigraphic section 1, it is a 4.3-m-thick layer of white tuff composed of fine ash to coarse ash and lapilli (as large as $5 \mathrm{~mm}$ ), is very thin to thin bedded and contains minor, small-scale softsediment folds. At stratigraphic section 4, it is poorly exposed but about $5.5 \mathrm{~m}$ thick and composed of very-light-gray, fine ash tuff containing distinct glass shards. The upper half of tephra layer B at stratigraphic section B may be mostly water-reworked tuff.

Tephra layer C-1 (tephra sample 2379-15J) is only exposed in the southernmost part of the Mount Annie NE quadrangle near stratigraphic section 1. Here it consists of a lower 1.1-m-thick yellow-gray tuff composed of 1-to 2-mm ash and exhibiting small-scale soft-sediment folds. The upper $0.5 \mathrm{~m}$ of unit $\mathrm{C}-1$ consists of water-reworked tuff with irregular laminae to very thin beds. A calcite-cemented tuff forms the topmost part of tephra layer C-1 at stratigraphic section 1 .

Tephra layer C (tephra samples 13384-9J and 2379-19J) is the most widely exposed and the most distinctive tephra unit in the Cobble Cuesta area. It extends from the northern to the southern outcrop areas of map unit Ts. At stratigraphic section 1, it is a 4$\mathrm{m}$-thick, yellow-gray, coarse ash to lapilli tuff with sparse biotite. The lapilli are as large as $1 \mathrm{~cm}$. Commonly the tuff weathers to form $1-$ to $1.5-\mathrm{cm}$-long elliptical pellets that appear to have been derived from calcite-cemented concretionary structures in the tuff. At stratigraphic section 4, tephra layer $\mathrm{C}$ is a 4-m-thick ash to lapilli (as large as $1 \mathrm{~cm}$ ) tuff with sparse biotite. Elsewhere tephra layer $\mathrm{C}$ is similar and always characterized by lapilli (locally as large as $3 \mathrm{~cm}$ ) and by sparse biotite. About $2.4 \mathrm{~km}$ south of stratigraphic section 1 , tephra layer $\mathrm{C}$ is about $4 \mathrm{~m}$ thick and composed of coarse ash to lapilli as large as $2 \mathrm{~cm}$ and sparse biotite. At this location, the tephra layer $\mathrm{C}$ contains irregular lenses and layers of black vitrophyre produced in an airfall tuff.

Tephra layer D extends from about $0.4 \mathrm{~km}$ north of stratigraphic section 3 to 1.7 $\mathrm{km}$ south of stratigraphic section 1 . At stratigraphic section 3, it is a 14.9-m-thick unit composed of three separate tuffs, (1) a basal tuff (tephra sample JS-92-62), $24 \mathrm{~cm}$ thick, composed of fine ash, (2) a 30-cm-thick fine ash tuff (tephra sample JS-92-63) about 4 meters above the base of the unit, and (3) a fine vitric ash tuff (tephra sample JS-92-64) in the top $4.6 \mathrm{~m}$ of the unit. At stratigraphic section 2, tephra layer D consists of about $3 \mathrm{~m}$ of fine ash tuff, with sparse biotite. Most likely the tuff at stratigraphic section 2 correlates with the thick tuff at the top of tephra layer D at stratigraphic section 3. At stratigraphic section 1, tephra layer $\mathrm{D}$ is poorly exposed but appears to consist of at least two fine ash tuffs in a stratigraphic interval of about $19 \mathrm{~m}$.

Tephra layer EL (tephra sample JS-92-65) extends from $2.3 \mathrm{~km}$ south of stratigraphic section 3 to about $1 \mathrm{~km}$ north of stratigraphic section 5 . At stratigraphic section 3, it consists of a 9.1-m-thick white to yellow-gray tuff composed of a mixture of ash and fine to coarse grains of quartz, biotite, and lithic fragments. Common opalized layers and nodules, and vertical or inclined tubular structures about 2 to $5 \mathrm{~mm}$ in diameter (probably root structures) characterize the subunit. The top $1 \mathrm{~m}$ of the subunit is a $1-\mathrm{m}-$ thick pale-yellowish-orange fine- to medium-grained ash. Much, if not all, of tephra layer EL at stratigraphic section 3 appears to be water-reworked tuff. At stratigraphic section 4, tephra unit EL is a 5.5-m-thick very-light-gray tuff, and silicified tuff, composed of fine ash (locally with shard structure), sparse biotite, and lithic fragments. Tubular structures, like those at stratigraphic section 3, are also present in tephra layer EL at stratigraphic section 4. At stratigraphic section 5, tephra layer EL is poorly exposed but at least $0.5 \mathrm{~m}$ of light-gray vitric ash tuff with distinct shard structure is present.

Tephra layer EU (tephra samples JS-92-66, 2379-12J, and 2-96-46J) extends from $1.3 \mathrm{~km}$ north of stratigraphic section 3 to $1.5 \mathrm{~km}$ south of stratigraphic section 1 . Tephra layer EU lies stratigraphically close to unit EL and the two units form a double-layered band of light-colored rock on the outcrop. At stratigraphic section 1, tephra layer EU is a 0.3 -m-thick layer of white, reworked, fine ash containing 20 percent grains of quartz and 
feldspar(?). At stratigraphic section 2, tephra layer EU is a 0.3-m-thick white tuff with shard structure. At stratigraphic section 3, tephra layer EU is a 2.4-m-thick white tuff composed of fine vitric ash with shard structure.

Tephra layer E+1 (tephra sample 2-94-16J) is the highest tephra unit mapped separately. It extents from $1.6 \mathrm{~km}$ south of stratigraphic section 1 to $0.9 \mathrm{~km}$ north of stratigraphic section 2. At stratigraphic section 1, it consists of two 0.2- to 0.3-m-thick, fine ash layers in a $2.6-\mathrm{m}$ interval. The lower tuff appears to be a reworked fine-ash tuff and the upper tuff is vitric ash tuff with shard structure. At stratigraphic section 2, tephra layer $\mathrm{E}+1$ is about $10 \mathrm{~m}$ thick and contains four individual layers ranging in thickness from 0.3 to $1 \mathrm{~m}$. Tuff at the base and the top of the unit are vitric shard tuffs, the second highest tuff is fine to medium ash with minor quartz and biotite crystals, and the third highest tuff is fine to medium ash with 20 to 30 percent fine- to coarse-grained quartz and biotite. The third highest tuff is calcareous and contains tubular structures that may be the remains of roots similar to those in tephra unit EL.

Map units $\operatorname{Tg}_{1}, \operatorname{Tg}_{2}, \operatorname{Tg}_{3}$, and $\operatorname{Tg}_{4}$. These unit consist of gravel or slightly consolidated gravel or conglomerate composed of subrounded to subangular clasts generally about 10 to $20 \mathrm{~cm}$ in diameter, but locally as large as $1 \mathrm{~m}$, of andesite and basalt, and minor amounts of welded tuff, flow-banded rhyolite, phyllite, and hornfels. Clasts of andesite and basalt are significantly more abundant in these units than in conglomerate of map unit Ts. Clasts of phyllite and hornfels were recognized only in the gravel at the top of stratigraphic section 3. The phyllite and hornfels clasts were apparently derived from Mesozoic units that are exposed in nearby areas.

$\mathrm{Tg}_{1}, \mathrm{Tg}_{2}, \mathrm{Tg}_{3}$, and $\mathrm{Tg}_{4}$ form lenticular, and in part intergrading, units. Unit $\mathrm{Tg}_{1}$ is somewhat finer grained than the other gravel units. It grades laterally into the upper part of map unit Ts near stratigraphic section 2 and as well as with the lower part of unit $\mathrm{Tg}_{4}$ south of stratigraphic section 1 .

\section{Tephrochronology}

Tephra layers (ash beds and tuffs) were sampled from natural outcrops in the field within the mapped areas of the Cobble Cuesta area (Fig. 3). Volcanic glass shards from these layers were separated and analyzed using methods described by Sarna-Wojcicki and others (1984). In brief: samples were wet-sieved with water in plastic sieves fitted with nylon screens, retaining the 200 to 100 mesh size fraction ( $~ 80$ to $\sim 150 \mathrm{~mm}$, respectively) for separation of glass shards. This fraction was placed in an ultrasonic vibrator in water, then treated with a $10 \%$ solution of $\mathrm{HCl}$ for a few minutes, to remove authigenic carbonate adhering to the glass particles, and with an $8 \%$ solution of $\mathrm{HF}$ for about 30 seconds to one minute, to remove other coatings or altered rinds that may have been present on the glass shards. The glass shards were then separated from other components of the tephra sample using (1) a magnetic separator and (2) heavy liquids of variable density made from mixtures of methylene iodide and acetone.

The glass separates were mounted in epoxy resin in shallow holes drilled into plexiglass slides, and the slides were ground-down and polished with diamond paste to expose the shards and prepare a smooth, uniform surface for analysis. The polished sample was coated with carbon, and individual shards were analyzed by electron-microprobe, using the JEOL 8900 instrument (note: use of tradenames in this report is for informational purposes, and does not represent endorsement of the product by the U.S. Geological Survey). See Sarna-Wojcicki and others (1984), and Sarna-Wojcicki and others (1985), for specifics of analytical conditions.

The polished glass shards were analyzed for $\mathrm{Si}, \mathrm{Al}, \mathrm{Fe}, \mathrm{Mg}, \mathrm{Mn}, \mathrm{Ca}, \mathrm{Ti}, \mathrm{Na}$, and $\mathrm{K}$. Approximately 15 to 20 shards were analyzed from each sample. Some samples contained two or more compositional modes, and each mode was compared separately . Results of analyses were compared with our data base of approximately 4,200 previously analyzed samples of volcanic glasses from upper Neogene tephra layers collected within the conterminous western U.S. and from bottom sediments of the adjacent Pacific Ocean. The best matches were identified 
using numerical and statistical programs (SIMANAL; Sarna-Wojcicki and others, 1984). The best matches were then examined for petrographic similarities and for stratigraphic position and sequence (Sarna-Wojcicki and Davis, 1991). Correlative layers were identified on the basis of these three main criteria: (1) chemical composition of volcanic glass, (2) petrographic characteristics, and (3) stratigraphic position. Comparisons of tephra layers for the purpose of correlation were made with several different combinations of elements, excluding those elements that are present in concentrations close to the detection limit when comparing sample groups.

Twenty-seven samples of tephra were collected from the Miocene strata in the Cobble Cuesta area. These samples were analysed for major elements (Table 1) and the tephra layers were correlated on the basis of the chemical compositionof the glass shards with other analysed tephra in Nevada, Utah, and Idaho (Table 2). This analysis revealed that map unit Ts, the main unit exposed in the Cobble Cuesta area, ranges in age from 12.96 to at least $9.24 \mathrm{Ma}$. The uppermost part of unit Ts is undated, but probably about 9 Ma old, based on the uppermost part of unit Ts being stratigraphically close to strata dated as 9.24 Ma. Map units $\mathrm{Tg}_{1}, \mathrm{Tg}_{2}, \mathrm{Tg}_{3}$, and $\mathrm{Tg}_{4}$ are less than about $9 \mathrm{Ma}$, and probably of late Miocene and perhaps, in part, of Pliocene age.

\section{Paleocurrent directions}

Studies of paleocurrent directions were made at 11 localities in map unit Ts, at one locality in $\mathrm{Tg}_{3}$, and at one locality in $\mathrm{Tg}_{4}$ (Fig. 6,7). These studies consist of measurements of the dip direction of cross-strata, of the downcurrent trends of troughs of cross-strata, of the downcurrent trends of channels in sandstone and conglomeratic sandstone and of the imbrication of clasts in conglomerate or gravel. In many places crossstrata are difficult to see because the strata are semiconsolidated and the cross-strata are obscured. Because of this problem, studies were generally made in areas where strata are somewhat indurated. The number of measurements at an individual locality is generally the total number of cross-strata that could be found. Studies of imbrication were made by measuring the strike and dip of flat surfaces on tabular or bladed clasts. About 30 to 50 surfaces of clasts were measured, if possible. For both cross-strata and imbrication, field measurements were corrected for the structural dip of the unit so that the final result indicates the original paleocurrent direction, assuming no major structural folding or rotation. The results of the paleocurrent studies are shown on figures 4 and 5. On these figures, the dip direction of imbrication, which is inclined upcurrent (180 degrees from the downcurrent inclination of cross-strata) is rotated 180 degrees so that the direction shown on the rose diagrams indicate the downcurrent direction.

The paleocurrent studies indicate a overall southward direction of current flow (Fig. 6). Results at individual localities (Fig. 7) indicate flow directions ranging from southwest to southeast.

\section{Environments of deposition}

The sandstone and conglomerate of map unit Ts are considered to be mostly low energy stream deposits. This interpretation is based on the predominance of fined-grained sandstone and granule to small-pebble conglomerate and on the presence of trough crossstratification. Large-scale deltaic cross-strata were noted near Long. $118^{\circ} 51^{\prime} \mathrm{W}$, Lat. $38^{\circ} 57^{\prime} \mathrm{N}$. Possibly some of the conglomerate layers are beach deposits, but evidence for or against this idea was not found.

Map units $\mathrm{Tg}_{1}, \mathrm{Tg}_{2}, \mathrm{Tg}_{3}$, and $\mathrm{Tg}_{4}$ are considered to be near-source alluvial-fan deposits. This interpretation is based on the coarse texture of these units (clasts as large as $1 \mathrm{~m}$ ), and the map patterns of these units which suggest, in part original lens-shaped crosssections. 


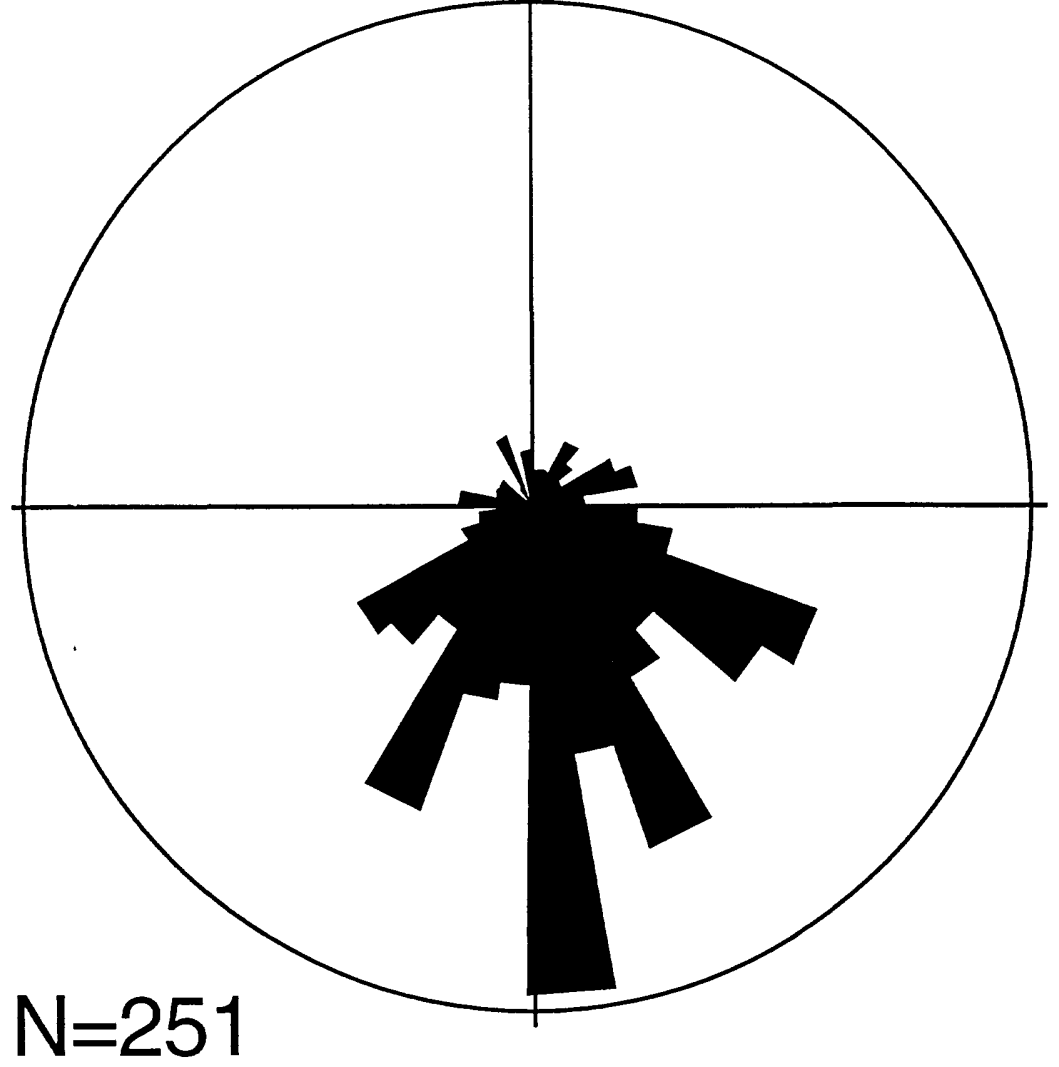

Cobble Cuesta, all data

Figure 6. Rose diagram showing summary of all paleocurrent measurements in Cobble Cuesta area. Total number of readings (N) is 251. Measurements consist of dip directions of individual cross-strata, trends of trough sets of cross-strata and of channels, and dip directions of individual disk- or blade-shaped clasts. The dip direction of imbricate clasts, which are inclined upcurrent, are rotated 180 degrees so that the data are consistent with the downcurrent direction of cross-strata, troughs, and channels. Measurements corrected for structural dip. 


\section{Structure}

The structure of Miocene and Pliocene(?) sedimentary rocks in the Cobble Cuesta area is simple. Stratal dips are generally less than about 20 degrees, and in many places less than 10 degrees. The area is cut by relatively few faults. Movement on some of the faults took place during the 1954 Paradise Peak earthquake (Ekren and Byers, 1986).

The dominant structure of the Cobble Cuesta area is a major north-south-trending anticline, here referred to as the Cobble Cuesta anticline. In map pattern, strata of this fold in map unit Ts commonly curve westward, and this curvature was considered by Ekren and Byers $(1984,1986)$ to indicate a drag fold on a major fault that approximately follows the contact of map units $\mathrm{Tg}_{4}$ and $\mathrm{Ts}$ on the present map. Such a fault could not be verified in the present study, and the contact between map map units Tg4 and Ts is considered here to be an unconformity. Map unit $\mathrm{Tg}_{4}$, as mapped, is folded as part of the anticline and extends unbroken (except for Quaternary cover) from the east limb to the west limb of the anticline.

Apparent unconformities within map unit Ts suggest that some structural movement, presumably normal faulting, occurred during deposition of map unit Ts. In the northern part of the map area, tephra layer $\mathrm{C}$ appears to cut across units in the underlying part of map unit Ts. Although outcrops are too poor to observe this unconformity in the field, units older than tephra layer $C$ curve to the east where they form the northern nose of the Cobble Cuesta anticline, but tephra layer $\mathrm{C}$ appears to cut cross these layers. $\mathrm{A}$ convergence of layers within map unit Ts is also notable north of stratigraphic section 5 . Here again exposures are poor and the an unconformity is suggested only by the map pattern.

The most conspicuous unconfomity in the Cobble Cuesta area is between map unit Ts and $\mathrm{Tg}_{4} . \mathrm{Tg}_{4}$ extends around the northern part of the anticline and rests progressively at lower stratigraphic levels to the west. Almost all of map unit Ts, perhaps about $800 \mathrm{~m}$, is cut out westward by map unit $\mathrm{Tg}_{4}$ along this unconformity.

The Cobble Cuesta anticline is best defined in the central area of outcrops of map unit Ts where the attitudes of strata can be measured. However, the anticline appears to be a much larger feature than the axial area mapped within map unit Ts. This is suggested by the broad, upland, anticlinal-shaped area developed on map unit $\mathrm{Tg}_{4}$ and on associated gravels such as $\mathrm{Tg}_{1}, \mathrm{Tg}_{2}$, or $\mathrm{Tg}_{3}$. This anticlinal-shaped upland area paradoxically forms much of the central part of Gabbs Valley (Fig. 2). The shape of this upland area, and its position adjacent to the mapped axial trace of the Cobble Cuesta anticline indicate that it is part of the Cobble Cuesta anticline.

\section{Paleogeography and structural setting}

The sedimentary strata in the Cobble Cuesta area are interpreted to have been deposited near the western side of a simple or complex graben or half graben (Fig. 8) where sedimentary transport was mainly parallel to the long axis of the graben. Such a pattern is suggested by the inferred location of a major basin-and-range north-northeasttrending normal fault along the eastern side of Monte Cristo Mountains west of the Cobble Cuesta area, and by the general southerly direction of paleocurrent flow in map units Ts, $\mathrm{Tg}_{3}$, and $\mathrm{Tg}_{4}$. Although the Monte Cristo Mountains lie close to the Cobble Cuesta area to the west, they apparently contributed only a minor amount of sediment to the Cobble Cuesta basin. This is suggested the lack of coarse, angular, near-source detritus in map unit Ts in the Cobble Cuesta area. Perhaps the mountains west of the Miocene Cobble Cuesta area had low relief, in spite of the fact that unconformities within the deposition basin suggest nearby faulting. The faults may have been intrabasinal and the sedimentary basin may have extended significantly farther west than its present outcrops area. Some detrital material in map unit Ts near the Monte Cristo Mountains is coarser than that in Ts in 


\section{Cobble Cuesta}

anticline

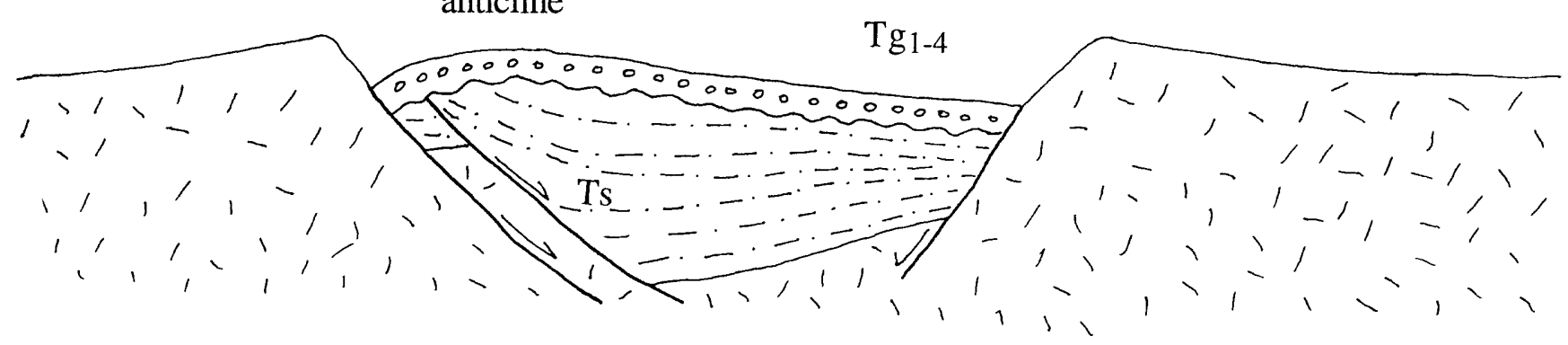

D. $<10 \mathrm{Ma}$ to present-day. East tilt of Miocene strata in eastern part of basin along west dipping faults and west tilt (reverse drag) in western part of of basin along east dipping faults, producing the Cobble Cuesta anticline in central part of Gabbs Valley

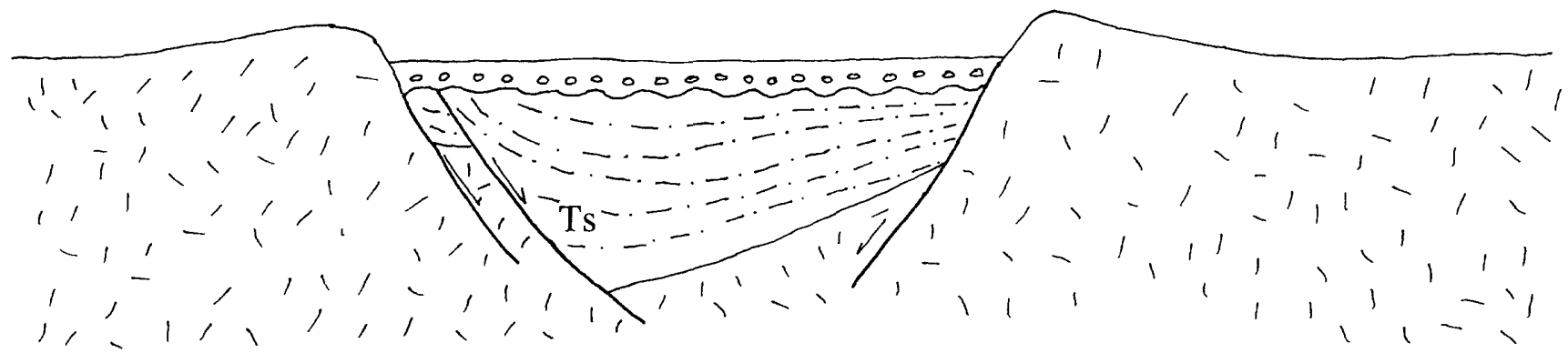

C. $<10$ Ma. Deposition of gravel of $\mathrm{Tg}_{1-4}$ unconformably on Miocene strata.

Development of high topography relief similar to that of present-day

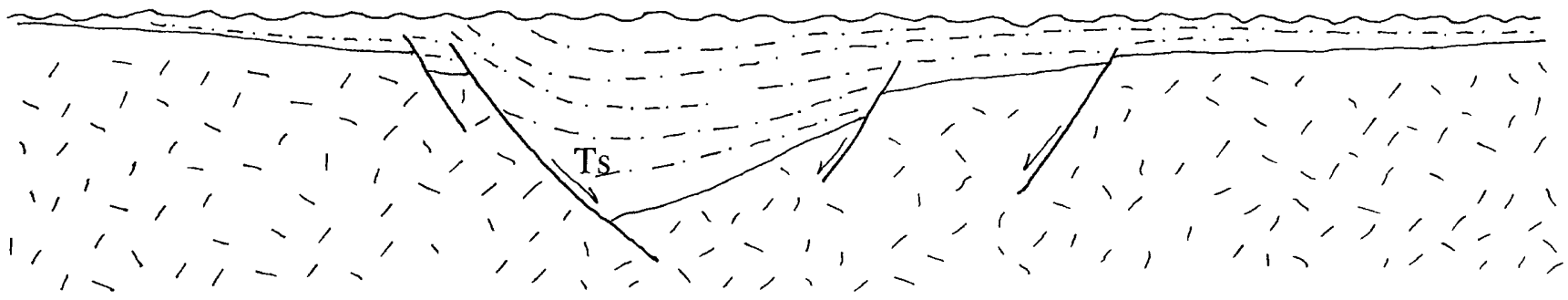

B. About $10 \mathrm{Ma}$. Normal drag of Miocene strata along fault, or faults, on west side of basin, producing east dip of strata, followed by erosion

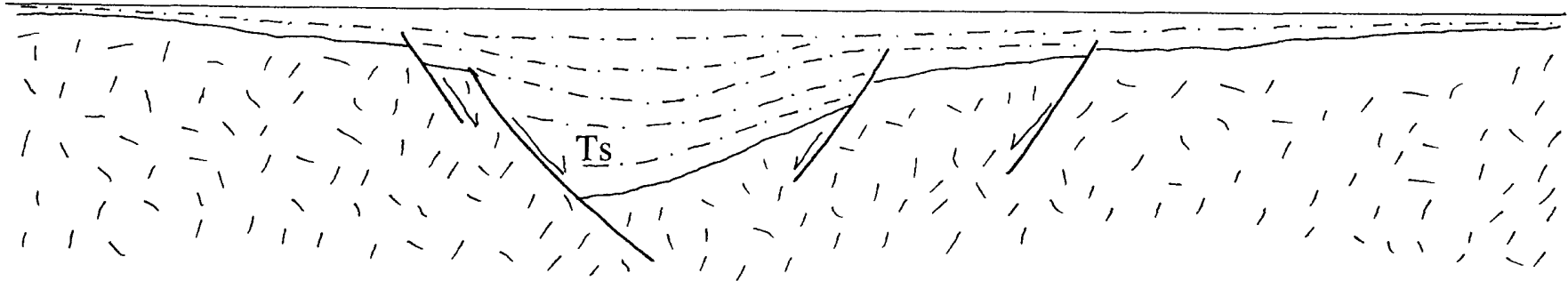

A. >13 Ma to $10 \mathrm{Ma}$. Deposition of Miocene strata (Ts) in Gabbs Valley basin. As much as 4,000 m of low-density material (presumably mostly Miocene strata) are present in Gabbs Valley based on gravity analysis of Jachens and others (1996). Low topographic relief; no coarse near-source strata. Basin probably much larger than present-day Gabbs Valley

Figure 8. Interpretive diagram showing development of Gabbs Valley basin 
the Cobble Cuesta area, but the clasts are subangular to subrounded, not angular as would be expected from a near-source terrain. Sedimentary transport parallel to the valley and only minor coarse near-source deposits is characteristic of many areas in the present-day Basin and Range province

The original size and shape of the sedimentary basin that included the Cobble Cuesta area is difficult to determine. The absence of coarse near-source clastic detritus in map unit Ts in the Cobble Cuesta area suggests that the basin may have extended for some unknown distance to the west of Cobble Cuesta. To the east and southeast, a large gravity low in Gabbs Valley is interpreted (Jachen and others, 1996) to contain about 4,000 m of low density material, presumably Miocene sedimentary rocks. The basin may have originally connected with the Stewart Valley basin (Schorn and others, 1989; Stewart, 1992) about $40 \mathrm{~km}$ south southeast of Cobble Cuesta. This connection is suggested by the presence of discontinuous outcrops of Miocene sedimentary rocks between Cobble Cuesta and Stewart Valley and partial overlap in age of strata in the Cobble Cuesta area (12.96 to $<9.24 \mathrm{Ma}$, this report) and that in the Stewart Valley area (11.19 to $15.24 \mathrm{Ma}$, Perkins and others, 1998).

The Cobble Cuesta anticline seems like an anomally in the extensional Basin and Range province, yet the work of Rosendahl (1987), Scott and Rosendahl (1989), and Faulds (1994) and Faulds and Varga (1998) indicates that mid-graben anticlinal structure parallel to normal faults bounding the graben are common in areas of extension. Such structures have been referred to as low relief accommodation zones (Rosendahl, 1987), interference accommodation zones (Scott and Rosendahl, 1989), convergent collateral accommodation zones (Morley and others, 1990), and anticlinal accommodation zones (Faulds and Varga, 1998). I will use the term anticlinal accommodation zone in this paper. As described by these geologists, anticlinal accommodation zones form in downdropped blocks between oppositely inclined, inward dipping, normal faults on either side of a graben. Backward rotation and outward movement of blocks along these opposing faults produces areas along the sides of the graben where dips are toward the sides of the graben, yet the mid-graben area is relatively unaffected. This situation of backward rotation (dips away from the graben axis) of strata along the sides of the graben and little rotation in the mid-graben area produces an anticline.

The Cobble Cuesta anticline can be considered an anticlinal accommodation zone. A major fault on the northeast side of the Cobble Cuesta area is apparent (Ekren and Byers, 1986), and an opposing fault is known (Kleinhampl and Ziony, 1985), or inferred, along the eastern side of Gabbs Valley (Figure 2). Oppositely directed normal faulting and backward rotation of blocks on the margins of Gabbs Valley is interpreted to have produced the Cobble Cuesta anticline (Figure 8).

\section{REFERENCES CITED}

Eastwood, W.C., 1969, Trace element correlation of Tertiary volcanic ashes from western Nevada: Berkeley, University of California, M.A. thesis

Ekren, E.B., and Byers, F.M., Jr., 1976, Ash-flow fissure vent in west-central Nevada: Geology, v. 4, no. 4, p. 247-251.

Ekren, E.B., and Byers, F.M., Jr., 1984, The Gabbs Valley Range--A well-exposed segment of the Walker Lane in west-central Nevada, in Lintz, Joseph, Jr., ed. Western Geological Excursions, vol. 4: Geological Society of America Annual Meeting: Reno, Nevada, Mackay School of Mines, p. 203-215.

Ekren, E.B., and Byers, F.M., Jr., 1986, Geologic map of the Mount Annie NE, Mount Annie, Ramsey Spring, and Mount Annie SE Quadrangles, Mineral and Nye Counties, Nevada: U.S. Geological Survey Miscellaneous Field Investigations Series Map I-1579, 1:48,000 scale

Ekren, E.B., Byers, F.M., Jr., Hardyman, R.F., Marvin, R.F., and Silberman, M.L., 1980, Stratigraphy, preliminary petrology, and some structural features of Tertiary 
volcanic rocks in the Gabbs Valley and Gillis Ranges, Mineral County, Nevada: U.S. Geological Survey Bulletin 1464, 54 p.

Faulds, J.E., 1994, New insights on the geometry and kinematics of the Black MountainsHighland Spring Range accommodation zone (BHZ), Arizona and Nevada:

Geological Society of America, Abstracts with Programs, v. 26, no. 2, p. 51.

Faulds, J.E., and Varga, R.J., 1998, The role of accommodation zones and transfer zones in the regional segmentation of extended terranes, in Faulds, J.E., and Stewart, J.H., eds., Accommodation zones and transfer zones: The regional segmentation of the Basin and Range province, Geological Society of America Special Paper 323 , p. 1-45.

Jachens, R.C., Moring, B.C., and Schruben, P.G., 1996, Thickness of Cenozoic deposits and the isostatic residual gravity over basement, in D.A. Singer, ed., An analysis of Nevada's metal-bearing mineral resources: Nevada Bureau of Mines and Geology, NBMG Open File Report 96-2, p. 2-1 to 2-10.

Kleinhampl, F.J., and Ziony, J.I., 1985, Geology of northern Nye County, Nevada: Nevada Bureau of Mines and Geology Bulletin 99A, 172p.

Morley, C.K., Nelson, R.A., Ratton, T.L., and Munn, S.G., 1990, Transfer zones in the East African Rift system and their relevance to hydrocarbon exploration in rifts: American Association of Petroleum Geologists Bulletin, v. 74, p. 1234-1253.

Perkins, M.E., Brown, F.H., Nash, W.P., McIntosh, William, and Williams, S.K., 1998, Sequence, age, and source of silicic fallout tuffs in middle to late Miocene basins of the northern Basin and Range province: Geological Society of America Bulletin v. 110, no. 3, p. 344-360.

Rosendahl, B.R., 1987, Architecture of continental rifts with special reference to East Africa: Annual Review of Earth and Planetary Sciences, v. 15, p. 445-503.

Sarna-Wojcicki, A. M., and Davis, J. O., 1991, Quaternary Tephrochronology, in Morrison, R. B., ed., Quaternary nonglacial geology: conterminous United States. Geological Society of America, DNAG Series, V. K-2, p. 93-116.

Sarna-Wojcicki, A. M., Bowman, H. R., Meyer, C. E., Russell, P. C., Woodward, M. J., McCoy, Gail, Rowe, J. J., Jr., Baedecker, P. A., Asaro, Frank, and Michael, Helen, 1984, Chemical analyses, correlations, and ages of upper Pliocene and Pleistocene ash layers of east-central and southern California. U.S. Geol. Survey Prof. Paper 1293, 40 p.

Sarna-Wojcicki, A. M., Meyer, C. E., Bowman, H. R., Hall, N. T., Russell, P. C., Woodward, M. L., and Slate, J. L., 1985, Correlation of the Rockland ash bed, a 400,000-year-old stratigraphic marker in northern California and western Nevada, and implications for middle Pleistocene paleogeography of central California. Quaternary Research, v. 23, p. 236-257.

Schorn, H.E., Scudder, H.I., Savage, D.E., and Firby, J.R., 1989, General stratigraphy and paleontology of the Miocene continental sequence in Stewart Valley, Mineral County, Nevada, U.S.A., in Liu, Gengwu, Tsuchi, Ryuichi, and Lin, Qibin, eds., Proceedings of International Symposium of Pacific Neogene Continental and Marine Events, National Working Group of China for IGCP-246: Nanjing, China, Nanjing University Press, p. 157-173.

Scott, D.L., and Rosendahl, B.R., 1989, North Viking Graben: An East African perspective: American Association of Petroleum Geologists, v. 73, no. 2, p. 155165

Stewart, J.H., 1992, Paleogeography and tectonic setting of Miocene continental strata in the northern part of the Walker Lane Belt, in Craig, S.D., ed., Structure, tectonics, and mineralization of the Walker Lane, Walker Lane Symposium, Proceedings Volume: Reno, Nevada, Geological Society of Nevada, p. 1-16.

Stewart, J.H., Sarna-Wojcicki, Andrei, Meyer, C.E., Starratt, S.W., and Wan, Elmira, 1999, Stratigraphy, tephrochronology, and structural setting of Miocene sedimentary 
rocks in the Middlegate area, west-central Nevada: U.S. Geological Survey Open File Report 99-350, 17 p.

Stewart, J.H., and Perkins, M.E., 1999, Stratigraphy, tephrochronology, and structure of part of the Miocene Truckee Formation in the Trinity Range-Hot Springs Mountains area, Churchill County, west-central Nevada: U.S. Geological Survey Open File Report 99-330, 25 p. 